\title{
Association of viral load and ALT level among HCV-infected Bangladeshi patient with different genotypes
}

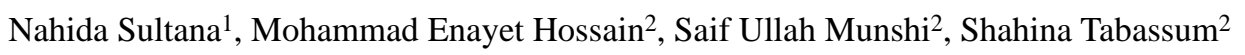 \\ ${ }^{1}$ Department of Virology, Bangabandhu Sheikh Mujib Medical University, Shahbag, Dhaka-1000. Virology Laboratory \& \\ Infectious Disease Division (Emerging I nfection), International Center for Diarrhoeal Diseases Research Laboratory
}

\begin{abstract}
Hepatitis C virus (HCV) causes chronic infections that mainly affect the liver leading to hepatic fibrosis followed by development of cirrhosis and hepatocellular carcinoma (HCC). Several factors including HCV genotype have been proposed to associate with the clinical outcome of HCV infection.This study was aimed to determine whetherthere is any significant differencein HCV viral load and Alanine Aminotransferase (ALT) in relation to genotypesin HCV infected Bangladeshi patients.After quantification of HCV viral load, 36 samples were randomly selected for HCV genotyping and ALT measurement. Themean HCV viral load of genotype 1 infected patients was $14.11 \pm 6.77[\log 10($ copies $/ \mathrm{m})$ )] while it was $12.80 \pm 2.05[\log 10($ copies $/ \mathrm{m})$ )] for genotype 3 infected patients. The mean ALT level of genotype 1 and genotype 3 infected patients were 51.2 $\$ 34.4 \mathrm{U} / \mathrm{L}$ and 89.6 $\pm 86.6 \mathrm{U} / \mathrm{L}$ respectively. There was no significant statistical difference in serumALT or plasma viral load between genotype 1 and genotype 3 infected patients.In HCV infection, genotype may have no relation to viral load and serum ALT level among Bangladeshi patients.
\end{abstract}

K ey words: HCV genotype, AlanineAminotransferse (ALT), HCV viral load.

\section{Introduction:}

Hepatitis $\mathrm{C}$ virus (HCV) is a major cause of liver associated diseases all over the world. An estimated $3 \%$ of the world populations are chronically infected with $\mathrm{HCV}$, which is the main cause of liver fibrosis, cirrhosis and hepatocellular carcinoma (HCC) in a substantial number of patients. ${ }^{1,2}$ It has been estimated in 2014 that globally 350,000 individuals die annually for HCV infection due to life-threatening complications, which include cirrhosis and hepatocellular carcinoma. ${ }^{3}$ Countries with the highest reported rates of HCV infection are situated in East Asia, Africa, North America. 8,9 Bangladesh has shown low endemicity forHCV. ${ }^{10}$ Due to considerable sequence diversity and sequence comparisons in different parts of HCV genome, viruses are classified into a

\section{Correspondence:}

Dr. Nahida Sultana

ResearchAssistant

Department Of Virology

Bangabandhu Sheikh Mujib Medical University, Shahbag, Dhaka-1000

E mail: nahida.sultanabd@gmail.com

Contact: 01744294543 series of genotypes which are distinct geographically in their frequency distribution across the whole world. $4,5,6,7$

$\mathrm{HCV}$ is a singlestranded linear RNA virus with a high mutationrate; an estimated frequency of $10^{2}$ mutationspernucleotide per year. ${ }^{11}$ Its genome is approximately $9.6 \mathrm{~kb}$ long, and consists of a single open reading frame encoding apolypeptidechain of 3000 amino acids. ${ }^{12}$ The number of recognized HCV genotypes has recently increased from six to seven, and numbers of recognized subtypes has greatly expanded to 67.1 .3 Genotypes 1,2 , and 3 are the most prevalent genotype gl obal ly, ${ }^{14}$ while othergeno types are limited to specific regions. HCV genotyping provides information about variability in the viral genome, likely disease progression and possible treatment strategies. ${ }^{15}$ The most common genotypes, collectively accounting for approximately $80 \%$ of the infections in the Bangladeshi population are reportedly $3 \mathrm{~b}$, followed by $1 \mathrm{la}$ and $3 a$ whereas $4 a, 4 c, 2 a, 2 c$ were less commonly detected. ${ }^{16}$

In HCV infection, various factors that are important in predicting the outcome of disease progression include 
duration of infection, genotype/subtype, gender of the patient, mode of infection and viral load. ${ }^{17} \mathrm{HCV}$ genotypes and viral load are strong predictors for the outcome of antiviral therapy. ${ }^{18,19}$ Determination of viral loads and serum ALT level is useful for monitoring both treatment responses and relapse rates. ${ }^{20}$ ALT is a very specific and well defined indicator of liver status during chronic diseases as it is concentrated in the liver and released in the bloodstream during hepatocyte necrosis or apoptosis. ${ }^{21}$ As increase level of ALT indicates the liver injury and increase HCV-RNA indicates replication status of $\mathrm{HCV}$, several authors tried to correlate viral and host factors like genotype, viral load, ALT etc. with each other as well as with liver injury, but no clear conclusions were formed. ${ }^{22,23,24,25,26}$ The purpose of this study was to observe whether viral load and ALT level differ in relation to genotypes among the HCV-infected Bangl adeshi patients or not.

\section{M ethods and M aterials:}

Patient Selection: A total of 534 Anti-HCV positive patients were enrolled in this study who provided blood at the Department of Virology, BSMMU for HCV RNA quantification. After HCV viral load quantification, $217 \mathrm{HCV}$ RNA positive patients who had viral load $>600 \mathrm{lU} / \mathrm{ml}$ were selected and from them, $36 \mathrm{HCV}$ RNA positive patients were randomly sel ected for genotyping and ALT measurement

Sample Collection: Under aseptic condition $5 \mathrm{ml}$ of blood was collected from each patient and kept in two separated tube (vacutainer for serum and EDTA tube for plasma) for separation of serum and plasma simultaneously. All the samples were stored at $-2^{\circ}$ Cfor HCV-RNA quantification, ALT assay and HCV genotyping. These laboratory procedures were performed at the Department of Virology, BSMMU, Department of Biochemistry, BSMMU and ICDDRB respectively.

RNA extraction: HCV-RNA was extracted from $150 \mu$ of plasma using Instant Virus RNA KIT (Analytic Jena AG, Germany, cat. no-847-0209200502) according to the manufacturer's instruction. Extracted Viral RNA was el uted in RNase free water and stored at $-20^{\circ} \mathrm{C}$ until Real time PCR was performed.

HCV RNA Quantification: Quantification of HCV RNA in human plasma samples by Realtime RT PCR was performed using RoboGene ${ }^{\circledR}$ Hepatitis C Virus (HCV) RNA Quantification Kit, (Robogene, Germany, Cat.no 0207200104) in ABI 7300 SDS real time PCR machine (Applied Biosystems, USA) at the Department of Virology,
BSMMU. Twenty microlitre of Master Mix was pipette into each PCR tube and $5 \mu \mathrm{l}$ of eluted RNA sample was added into it. Finally total $25 \mu \mathrm{l}$ of reaction volume was used for quantification of HCV-RNA. PCR was performed with initial reverse transcription at $55^{\circ} \mathrm{C}$ for $30 \mathrm{~min}$, Taq activation at 95ㄷ $\mathrm{C}$ for $2 \mathrm{~min}$ followed by annealing at 5790 $\mathrm{Cor} 1 \mathrm{~min}$, melting at $95^{\circ} \mathrm{C}$ for $30 \mathrm{sec}$ and finally fluorescence detected at $45^{\circ} \mathrm{C}$ for $30 \mathrm{sec}$. Fluorescence signal were measured during 45 PCR cycle. The data analysis is performed according to manufacturer's instruction using the respective software. HCV RNA is determined based upon the CT values for the sample HCV RNA and a standard curve resulting from analysis of quantification standards and the assay specific calibration coefficient. HCV RNA concentration is express in IU/ml.

\section{NS5B gene amplification and HCV genotype determination by Sequencing:}

NS5B gene amplification by RT-PCR was performed using onestep RT-PCR kit (QIAGEN, Inc.) in a 25- $\mu$ l of reaction volume containing $5 \mu$ l of extracted RNA, 5X QIAGEN One Step RT-PCR buffer, 400 $\mu \mathrm{M}$ each dNTP (Amersham Biosciences Inc., Baied'Urfe, Quebec, Canada), $0.5 \mu \mathrm{M}$ sense and antisense primers (DM 100-TACCTVGTCATAGCCTCCGTGAA and DM101-TTCTCRTATGAYACCCGCTGYTTTGA), $2.0 \mu$ lQIAGEN One Step RT-PCR enzyme mix 10 U RNA guard RNase inhibitor (Amersham Biosciences Inc.), and $1 \mathrm{U}$ heat-labile uracil-DNA glycosylase (Roche Diagnostics, Laval, Quebec, Canada). Samples were incubated at $20^{\circ} \mathrm{C}$ for $10 \mathrm{~min}, 50^{\circ} \mathrm{C}$ for $30 \mathrm{~min}$, and $95^{\circ} \mathrm{C}$ for $15 \mathrm{~min}$. The amplification was performed for 40 cycles each consisting of $55^{\circ} \mathrm{C}$ for $30 \mathrm{~s}, 72^{\circ} \mathrm{C}$ for $60 \mathrm{~s}$, and $94^{\circ} \mathrm{C}$ for $15 \mathrm{~s}$ in a GeneAmp PCR System 9600 or 9700 (Applied Biosystems, FosterCity, CA). The Amplified products electrophoresedin $1.5 \%$ agarose gel with TBE buffer. After purified by the ExoSAP-IT (Affymetrix, California, USA) solution, the samples showinga band of the appropriate size (389 bp) were further analyzed for DNA sequencing. Sequencing was performed using the $\mathrm{ABI}$ Prism Big Dye Terminator cycle sequencing ready reaction kit v3.1 (A pplied Biosystems, USA) with AmpliTaq DNA polymerase FS and electrophoresed on an ABI Prism $3100 \mathrm{XL}$ genetic analyzer (Applied Bio-systems, USA). The chromatogram sequences were inspected with Chromas 2.3 (Technelysium, Australia), multiple sequence alignment was performed using Clustal W Multiple Alignment in Bioedit (Hall, 1999), version 7.1.3, and edited manually. The genotype of each sample was determined by comparing its sequence with those of $\mathrm{HCV}$ prototypes obtained from GenBank by NCBI. To identify the similarity of sequences all the sequences were submitted to 
online BLAST (basic local al ignment search tool) program at the National Center for Biotechnology Information website (available at: http://www.ncbi.nlmgov/BLAST/). Sequences were compiled and edited using the Laser gene sequence anal ysis software package (DNASTAR Inc, Madison, USA).

Measurement of ALT: The level of ALT in serum was measured by automatic biochemistry analyzer (Micro Lab300, Merck, Germany) using clinical chemistry kits (Human, Germany).

Statistical analysis The data were analyzed using the statistical package for social studied (SPSS, Chicago, IL, USA) version 22 for windows. All quantitative data were presented as means \pm standard deviations. Viral load was transferred by natural log for satisfying the condition of normality. Mean of two groups were compared by Student's unpaired t-tests and pvalue $<0.05$ was considered as significant.

\section{Results:}

In present study, all 36 samples were possible to sequence. Among them, 22 (44.9\%) patients were males and 14 (28.9\%) were females with a mean age of $43.53+13.03$ years (Age range: 23- 72 years).Out of $36 \mathrm{HCV}$ RNA positive patients, 31 (86.1\%) patients were infected with genotype 3 while only 5 (13.9\%) were infected with genotype 1 . No other genotypes were detected during this study. Out of these 36 patients, 7 (14.3\%) had past history of hepatitis, while $3(6.1 \%)$ had family history of hepatitis.

The mean HCV viral load of genotype 1 and genotype 3 infected patients were $14.11 \pm 6.77[\log 10($ copies $/ \mathrm{ml})]$ (Range:13.53 to $14.98[\log 10$ (copies/ml)]) and $12.80 \pm 2.05$ [log10 (copies/ml)] (Range: 7.17 to 15.82 [log10 (copies/m)]) (Table I). The mean ALT level of genotype 1 infected patients was $51.2 \pm 34.4 \mathrm{U} / \mathrm{L}$ (Range: 17 to $108 \mathrm{U} / \mathrm{L}$ ), while it was 89.6 $\pm 86.6 \mathrm{U} / \mathrm{L}$ (Range of 18 to $446 \mathrm{U} / \mathrm{L}$ ) for genotype 3 infected patients. There was no significant statistical difference in serum ALT $(p>0.05)$ or plasma viral load $(p=0.174)$ between genotype 1 and genotype 3 infected patients.

Table I: Comparison of HCV viral load [log10 (copies/ml)] and level of ALT (U/L) among patients infected with different HCV genotypes

\begin{tabular}{lllc}
\hline Characteristics & Genotype 1 & Genotype3 & P value \\
\hline Genotypes & $5(13.9 \%)$ & $31(86.1 \%)$ & - \\
Log Mean HCV viral load \pm SD & $(14.11 \pm 6.77)$ & $(12.80 \pm 2.05)$ & \\
(Range) & $(13.53-14.98)$ & $(7.17-15.82)$ & $0.174^{*}$ \\
Mean SerumALT level $\pm S D$ & $(51.2 \pm 34.4)$ & $(89.6 \pm 86.6)$ & \\
(Range) & $(17-108)$ & $(18-446)$ & $>0.05^{*}$ \\
\hline
\end{tabular}

- *Independent Students t test.

- $\mathrm{P} \leq 0.05$ indicates statistical significant.

\section{Discussion:}

The aim of this study was to compare viral load and liver enzyme ALT in patients infected with different HCV genotypes. For that the viral loads and ALT levels were analyzed among $36 \mathrm{HCV}$ infected Bangladeshi patients who were HCV viremic. The study revealed that both viral load and ALT level are two independent factors in compare with the detected genotypes. It has been debated whether subjects infected with HCV genotype 1 have higher serum HCV RNA levels than do those infected with other genotypes. ${ }^{25}$ Rong et al., (2011) and Chakravartiet al., (2011) were reported that genotype 1 was associated with significantly higher HCV RNA levels than genotype 3. 33,34,35 Other studies have also claimed such an association, as in a large US cohort of individuals with hemophilia ${ }^{36}$ and, more recently, in the RIBAVIC trial. ${ }^{37}$ The present study found that patients infected with genotype 1 had higher viral loads than those infected with genotype 3 but it was not statistically significant. Similarly, it al so has been reported previously that patients infected with genotype 1 were more likely to have insignificantly higher viral loads than those infected with genotype 2 and 3. 27,28,29,30,31,32 Insignificant high viral load in genotype 1 in all these study including present study may be due to fewer participants.

Raised serumALT is marker of Liver cell injury and cirrhosis is usually associated with elevated ALT levels. As different genotypes can lead to diverse severity of liver disease, the genotype detection might be useful in prevention of deadly complication of $\mathrm{CHC}$ such as cirrhosis and HCC. ${ }^{38}$ Relationships between the genotypes and serum ALT level are ambivalent, possibly due to the heterogeneity in HCV genetic variants. 39 In this study, it was found that ALT was insignificantly higher in genotype 3 as compared to genotype 1. It was reported earlier that genotype 3 is associated with insignificant higher ALT level that was similar to our study results. ${ }^{26,40}$ However, ljaz et al., (2011) observed correlation between HCV genotypes and serum levels of ALT. The researchers found that genotype 1 was associated with consistently and insignificantly higher serum levels of ALT than genotype 3.41 In another study, although higher mean values of ALT were observed in genotype 1 infected patients but there was no statistically significant association between HCV genotype or subtype and liver enzymes that was different from our study. 42,35 In contrast, observations from this study showed that most of the genotype 3 infected patients had insignificant elevated ALT levels that indirectly reflect more liver damage as compare to genotype 1 . 
Finally though this study showed genotype 3 is associated with higher levels of serum ALT and infection by genotype 1 is associated with the higher viral loads but no significant difference in HCV viral load and ALT among different genotype. One of the limitations of this study was small sample size to find out the HCV genotype specific differentiation with viral load and liver enzyme ALT. Further studies with large sample size shoul d be carried out to facilitate formulation of robust therapeutic and monitoring strategies.

\section{REFERENCES:}

1. Alter MJ . Epidemiology of hepatitis C. Hepatology 1997; 26:62S-65S.

2. Giannini $C$, Bréchot $C$. Hepatitis $C$ virus biology. Cell Death Differentiation 2002; 10:S27-38.

3. Shier MK, El-Wetidy MS, Ali HH, Al-Qattan MM.Characterization of hepatitis $C$ virus genotypes by directsequencingof HCV 5UTR region of isolates from SaudiArabia. PLOSONE2014; 9:e103160.

4. Abid K, Quadri R, Veuthey AL, HadengueA, Negro F. A novel hepatitis Cvirus (HCV) subtypes from Somalia and its classification into HCV Clade3. Joumal of General Virology 2000; 81:1485-1493.

5. Candotti DJ, Temple J, Sakodie F, Allain JP. Frequent recovery and broadgenotype 2 diversity characterize hepatitis $C$ virus infection in Ghana, West African J ournal of Virology 2003; 77(14):7914-7923.

6. Ndjomou J, Pybus OG, Matz B. Phylogenetic analysis of hepatitis $C$ virusisolates indicates a unique pattem of endemic infection in Cameroon. Journal of General Virology 2003; 84(9):2333-2341.

7. Simmonds P. Genetic diversity and evolution of hepatitis C virus-15years on. Journal of General Virology 2004; 85(11):3173-3188.

8. Messina JP, Humphreys I, Flaxman A, et al. Globaldistributionand prevalence of hepatitis $C$ virus genotypes. Hepatology2015; 61:77-87.

9. Bashir MF, Haider MS, Rashid N, Riaz S. Distribution ofhepatitisC virus (HCV) genotypes in different remotecities of Pakistan. Africanl ournal of Microbiology Res 2012; 6:4747-4751.

10. Mahtab MA, Rahman S, Karim MF, Khan M, Foster G, Solaiman S, Afroz S. Epidemiology of hepatitis B virus in Bangladeshi general population. Hepatobiliary Pancreatic Disease International 2008; 7(6):595-600.
11. Bartenschlager R, Lohmann V. Replication of hepatitis C virus. Joumal of General Virology 2000; 81(7): 1631-48.

12. Moradpour D, Penin F, Rice CM. Replication of hepatitis C virus. Nature reviews Microbiology 2007; 5(6):453.

13. Smith DB, Bukh J, Kuiken C, et al. Expanded classification ofhepatitis $C$ vinus into 7 genotypes and 67 subtypes: updatedcriteriaand genotype assignment web resource. Hepatology 2014; 59:318-327.

14. Messina JP, Humphreys I, Flaxman A, Brown A, Cooke GS, Pybus OG, Barnes E. Global distribution and prevalence of hepatitis $C$ virus genotypes. Hepatology 2015; 61(1): 77-87.

15. Simmonds P. Genetic diversity and evolution of hepatitis C virus-15 years on. Journal of General Virology 2004; 85(11):3173-88.

16. Islam MJ, Habib A, Jamiruddin R. Prevalence of hepatitis $C$ virus genotypes in Bangladesh. Hepatitis Monthly 2011; 6: 193-8.

17. Berry V, Arora R, Paul P. Hepatitis C-Clinical outcome and diagnosis. Journal of National Science 2005; 7:129-32.

18. Kumar D, Farrell GC, Fung C, George J. Hepatitis C virus genotype 3 iscytopathic to Hepatocytes: Reversal of hepatic steatosis after sustainedtherapeutic response. Hepatology 2002; 36:1266-1272.

19. Manns MP, McHutchison JG, Gordon SC, Rustgi VK, Shiffman M, Reindollar R, Goodman ZD, Koury K, Ling $M$, Albrecht JK: Peginterferonalfa $2 b$ plus ribavirin compared with interferon alfa-2b plus ribavirin forinitial treatment of chronic hepatitis C: a randomised trial. Lancet 2001;358:958-965.

20. Fanning L, Kenny E, Shechan M, Cannon B, Whelton M, O'Connell J. Viral load and clinicopathological features of chronichepatitis C (1b) in a homogeneous patient population. Hepatology 1999; 29:904-7.

21. Strader DB, Wright T, Thomas DL, Seeff LB. Diagnosis, management, and treatment of hepatitis C. Hepatology 2004; 39:1147-71.

22. El-Serag HB. Hepatocellular carcinoma and hepatitis C in the UnitedStates. Hepatology 2002; 36:S74-S83.

23. Azzari C, Resti M, Moriondo M, Ferrari R, Lionetti $P$, Vierucci A. Verticaltransmission of HCV is related to maternal peripheral bloodmononuclear cell infection. Blood 2000; 96:2045-2048.

24. Imbert-Bismut F, Ratziu V, Pieroni L, Charlotte F, Benhamou $Y$, Poynard T. Biochemical markers of liver 
fibrosis in patients with hepatitis C virusinfection: a prospective study. Lancet 2001; 357:1069-1075.

25. Kowala-Piaskowska A, Mozer-Lisewska I, Figlerowicz $M$, Sluzewski W.I nfluence of the presence of HCV-RNA in peripheral blood mononuclearcells on the clinical course of chronic hepatitis $C$ in children. Europian Journal of Epidemiology 2007; 22:343-348.

26. Pratt DS, Kaplan MM. Evaluation of abnormal liverenzyme results inasymptomatic patients. New England Journal of Medicine 2000; 342:1266-1271.

27. Scott JD, Gretch DR (2007). Molecular diagnostics of hepatitis C virus infection: a systematic review. Jama 2007; 297(7): 724-32.

28. Soriano V, Mocroft A, Rockstroh J, Ledergerber B, Knysz B, Chaplinskas S, Peters L, Karlsson A, Katlama C, Toro C, Kupfer B. Spontaneous viral clearance, viral load, and genotype distribution of hepatitis $C$ virus (HCV) in HIV-infected patients with anti-HCV antibodies in Europe. Journal of Infectious Diseases 2008; 198(9): 1337-44.

29. Mahaney K, Tedeschi V, Maertens G, Di Bisceglie AM, Vergalla J, Hoofnagle J H, Sallie R. Genotypic analysis of hepatitis C virus in American patients. Hepatology 1994; 20(6): 1405-11.

30. Berger A, Prondzinski MV, Doerr HW, Rabenau $H$, Weber B. Hepatitis C plasma viral load is associated with HCV genotype but not with HIV coinfection. J ournal of medical virology 1996; 48(4): 339-43.

31. Beld M, Penning M, Mc Morrow M, Gorgels J, van den Hoek A, Goudsmit J. Different hepatitis C virus (HCV) RNA load profiles following seroconversion among injecting drug users without correlation with HCV genotype and serum alanine aminotransferase levels. Journal of clinical microbiology. 1998;36(4):872-7.

32. Ahmed MM, Mutimer DJ, Martin B, Elias E, Wilde JT. Hepatitis C viral load, genotype and histological severity in patients with bleeding disorders. HAEMOPHILIAOXFORD 1999; 5:49-55.

33. Rong X., Lu L., WangJ (2011). Correlation of viral loads with HCV genotypes: higher levels of virus were reveal ed among blood donors infected with $6 a$ strains. PLOS ONE 2011; 7: e52467.
34. Chakravarti A, Dogra G, Verma V, Srivastava AP. Distribution pattern of HCV genotypes $\&$ its association with viral load. The Indian joumal of medical research 2011;133(3):326.

35. Berger A, Prondzinski MV, Doerr HW, Rabenau H, Weber B. Hepatitis C plasma viral load is associated with HCV genotype but not with HIV coinfection. J oumal of medical virology 1996; 48(4):339-43.

36. Yoo TW, Donfield S, Lail A, Lynn HS, Daar ES, Hemophilia Growth and Development Study. Effect of hepatitis $\mathrm{C}$ virus (HCV) genotype on HCV and HIV-1 disease. The Journal of infectious diseases 2005; 191(1):4-10.

37. Bani-Sadr F, Goderel I, Morand P, Payan C, Lune F, Pol $S$, Perronne C, Carrat F, Cacoub P. High hepatitis $C$ virus viral load in HIV/hepatitis C virus-co-infected patients: a different influence of protease inhibitor and non-protease inhi bitor-based HAART Aids 2007 ;21(12):1645-8.

38. Raymond E, Boige V, Faivre S, Sanderink GJ, Rixe O, Vemillet L, J acques C, Gatineau M, Ducreux M, Amand JP. Dosage adjustment and pharmacokinetic profile of ininotecan in cancer patients with hepatic dysfunction. J ournal of clinical oncology 2002;20(21):4303-12.

39. Al Swaff R. Correlation between al anine aminotransferase level, HCV-RNA titer and fibrosis stage in chronic HCV genotype 4 infection. Egyptian Journal of Medical Human Genetics 2012; 13(2): 207-12.

40. Kundu N, Gupta E, Rastogi A, Kumar G and Khurana J . Hepatitis C Virus (HCV) Genotype 3 is Associated with Higher Grade of Liver Fibrosis in Hepatitis C Virus Infected Patients. Joumal of HIV/AIDS Research 2016; 3(3):1030.

41. Ijaz B, Ahmad W, Javed FT, Gull S, Sarwar MT, Kausar H, Asad S, Jahan S, Khaliq S, Shahid I, Sumrin A (2011). Association of laboratory parameters with viral factors in patients with hepatitis C. Virology joumal 2011; 8(1): 1.

42. El-Zayadi A, Simmonds P, Dabbous H, Prescott L, Selim $\mathrm{O}$, Andy A. Response to interferon?? of Egyptian patients infected with hepatitis $C$ virus genotype 4 . Journal of viral hepatitis 1996; 3(5):261-4. 